\title{
Quality Matters Rubric Potential for Enhancing Online Foreign Language Education
}

\author{
Abdul Wahed Q. Al Zumor ${ }^{1}$ \\ ${ }^{1}$ School of Languages and Translation, King Khalid University, Abha, Saudi Arabia \\ Correspondence: Abdul Wahed Q. Al Zumor, Department of English, School of Languages and Translation, King \\ Khalid University, P.O. Box 9100, Abha, Saudi Arabia. Tel: 966-508-094-008. E-mail: aalzomr@kku.edu.sa
}

Received: November 12, 2014

Accepted: December 12, 2014 Online Published: March 30, 2015

doi:10.5539/ies.v8n4p173

URL: http://dx.doi.org/10.5539/ies.v8n4p173

\begin{abstract}
Quality Matters Program is designed to certify the quality of online courses in colleges and universities across and beyond the U.S. The Quality Matters Rubric (QMR) consists of eight general standards and 41 specific standards which are used to evaluate and design online and blended courses. The purpose of this study is to highlight the QMR standards that can contribute to providing a virtual learning space that caters for whole-person learning needs with special focus on EFL learners. In other words, the QMR has the potential to help in designing quality online courses that make EFL learning process more humanized and with a strong sense of instructors' and learners' presence that is sometimes neglected in online or blended learning environments. The typical characteristics attributed to Arab students are that they are obedient, uncritical, and unwilling to challenge the authority of teachers which are considered a challenge to the concept of autonomy in EFL learning. The design of EFL courses according to QMR standards is likely to make difference with regard to such cultural characteristics in a way that promotes learners' communicative competence.
\end{abstract}

Keywords: design-based research, EFL learning, input, interaction, quality matters rubric, social presence

\section{Introduction}

Enthusiastic embracing of technology for learning English among other disciplines in the Gulf higher education institutions is remarkable and worth researchers' attention. This sweeping move requires serious investigation and careful control. Some of the universities in the world have started regulating e-learning practices by establishing quality assurance measures to ensure best practices in course designing and course delivery.

Quality Matters Rubric, which is designed to certify the quality of online courses in colleges and universities across and beyond the U.S, has the potential to foster EFL learners' autonomy, interactivity, and "teaching presence" (Garrison, Anderson, \& Archer, 2000).

\section{Theoretical Framework}

\subsection{Design-Based Research}

Approaching the topic of the possible impact of the quality of course design on learning outcomes can be theoretically associated with design-based research (henceforth DBR) paradigm. DBR is a research approach that is being used more and more in education- particularly to investigate innovation using technology-based activities because it "embraces the complexity of learning and teaching" (Kelly, 2004). Moore and Kearsley (1996) emphasize the importance of online course-design when he defines Distance Education as "planned learning that normally occurs in a different place from teaching, requiring special course design and instruction techniques, communication through various technologies, and special organizational and administrative arrangements". Akyol and Garrison (2011) highlight the increased attention given today to the design of online courses for adults who are characterized as digital natives. They state that "Adult educators are now giving increased attention to designing online learning environments to meet adult learners' needs and expectations." They also argue that "Poorly designed online learning environments often result in unsuccessful or unsatisfactory educational experiences." Ducharme-Hansen and Dupin-Bryant (2005) indicate that problems with technology, building community, facilitating communication, or humanizing learning can sabotage educational efforts. 


\subsection{Constructivist Learning Environments (CLEs) and Technology}

The transition from traditional western theories to modern adult learning approaches indicates the shift from seeing learning as an individual activity to a more collaborative activity. Educators began to emphasize constructivist approaches and community building for more effective adult learning environments (Akyol \& Garrison, 2011).

CLEs are often defined as technology-based spaces in which students "explore, experiment, construct, converse, and reflect on what they are doing so that they learn from their experiences" (Jonassen, Peck, \& Wilson, 1999). CLEs have numerous advantages such as: more student-centered, collaborative learning, engaging and reflective. These advantages, however, do not happen spontaneously unless the learning environments are thoughtfully designed.

\subsection{Humanizing EFL Online Course Design}

When learning is moved to an online environment (be it fully or partially online), students report that they feel isolated, disconnected and alone in their learning experience which may decrease motivation and increase attrition (Bolliger \& Inan, 2012). Therefore, when learning occurs entirely (or partially) through computer-mediated instruction, an important part of the instructor's role is ensuring the learning environment is "people focused" or humanized (Ducharme-Hansen \& Dupin-Bryant, 2005). In such environment, the challenge in designing online courses is for faculty members to establish their teaching presence by humanizing the online classroom experience for their students (Jones, M. Kolloff, \& F. Kollof, 2008).

Humanizing an online learning environment particularly the foreign language environments is crucial for learning to take place successfully. Language, to some researchers, is defined primarily as a system of communication. It develops through interaction in social contexts with their instructors and with other students. When students relate to an online instructor as more than a subject-matter expert and begin to conceive of themselves as part of a larger community, they are more likely to be motivated, be satisfied with their learning, and succeed in achieving the course objectives (Picciano, 2002; Rovai \& Barnum, 2003; Richardson \& Swan, 2003).

Humanizing online course design requires maintaining both instructor presence and social presence. Instructor presence requires frequent, regular, and meaningful contact between the instructor and students. Social presence requires regular, meaningful interactions between students that foster the sense that individuals are real people and are part of a group or community.

\subsection{Social Presence}

Wegerif (1998) indicate that learners who do not feel part of a community "are on their own, likely to be anxious, defensive and unwilling to take the risk involved in learning" (p.48). Feeling a member of a community of inquiry is sometimes referred to as social presence. Short et al. (1976) describe social presence in technology based communication as a construct comprised of two concepts: intimacy (Argyle \& Dean, 1965) and immediacy (Mehrabian \& Wiener, 1966). It is the degree of person-to-person awareness, which occurs in a mediated environment. A lack of social presence may lead to a high level of frustration, a critical attitude towards the instructor's effectiveness, and a lower level of affective learning. Social presence means thought, emotion and behavior work together in our real-world experiences. The initial step for creating social presence in an online environment is to design online courses that provide a satisfying and effective learning environment.

\section{Quality Matters Rubric}

Quality Matters is a faculty-centered peer-review process designed to ensure quality in online and blended courses which is centered on a rubric developed by faculty from the University of Maryland under the FEBSI project. The rubric is based on the principles of instructional designing and is currently organized around eight general standards, namely course overview and introduction, learning objectives (competencies), assessment and measurement, instructional materials, learner interaction and engagement, course technology, learner support, and accessibility. The $5^{\text {th }}$ version of the Rubric comprises 43 specific standards within these eight general standards. The 43 specific standards are rated with 1, 2 or 3 points. There are 21 essential standards with a rating of 3 points and a course must meet all of these standards plus attaining a minimum score of 81 of 95 total points to meet the QM level of course design acceptance. Twelve of the standards are very important and with a rating of 2 points and eight are important with a rating of 1 point (MarylandOnline, 2013).

The Rubric is well-supported by research, comprehensive, and routinely updated. The latest version is the fifth edition of 2014 which is itself being modified based on research findings and best practices. The Rubric Standards are supported by annotations that contain explanations and examples (MarylandOnline, 2013). The 
QM Rubric gives special focus on the concept of "alignment" of the second, third, fourth, fifth and sixth standards. These critical course elements should work together to ensure that students achieve the desired learning outcomes.

Although little research to date has explored links between QM and learning outcomes, preliminary research (Legon, Runyon, \& Aman, 2007) found higher grades and greater student interaction with course materials after redesign of a large enrollment undergraduate course. In another study by Swan et al. (2008) it is indicated that "Student performance may have improved because the QM revision led instructors to focus on objectives and the mapping of objectives to outcomes, and that such focus translated into their activity in the course".

\section{Quality Matters Rubric Analysis: Potential Contribution to Learning English as a Foreign Language}

This section deals with the main focus of the study. Based on a deep look at the specific standards under the eight general ones, the researcher attempts to highlight the potential of QM Rubric to support the EFL learning environment. It has been observed that certain sub-standards can contribute tremendously to the creation of a constructive and interactive environment for learning English or any other foreign language. The discussion below presents the QM Rubric in its 2011-2013 version with special focus on the specific standards that are likely to help EFL learners and teachers.

\subsection{General Standard 1}

Under this general standard there is specific standard (1.3) which states that "Etiquette expectations (sometimes called "netiquette") for online discussions, email, and other forms of communication are stated clearly." The illustrations given in the annotations under this standard include the following:

1) Rules of conduct for participating in the discussion board

2) Rules of conduct for email content

3) "Speaking style" requirements (e.g., use of correct English required as opposed to popular abbreviations used online).

\section{4) Spelling and grammar expectations, if any}

5) Expectations for the tone and civilityused in communicating with fellow students and the faculty member, whether the communication be via electronic means or telephone or face-to-face

For any online or hybrid course design to meet QM requirements it has to take these annotations into consideration. Once these linguistic instructions are made clear to learners as compulsory, refined language production, whether in the discussion board or email communication, will occur. The use of proper style, correct spelling and grammar and maintaining the proper tone and civility in communication can contribute to enhancing the quality of EFL learners' communicative competence. Categorized as a very important standard in the Rubric, it is expected that instructors will work hard with their students to meet this linguistic requirement. Learners' pragma-linguistic and socio-pragmatic competences are likely to improve. They will be busy producing real and authentic language when they communicate with their instructors or peers adhering to the social rules and the proper style. Such an advantage is almost lacking in an EFL environment where the learners are normally exposed to limited quantity of L2 authentic input.

The specific standards (1.7 and 1.8) which respectively state as "The self-introduction by the instructor is appropriate and available online" and "Students are asked to introduce themselves to the class" both contribute to creating social presence in the learning environment and to maximizing opportunities for natural input and output. According to this standard's annotations "the initial introduction (by the teacher) creates a sense of connection" and "the students' introduction helps to create a supportive learning environment and a sense of community". Barab et al. (2003) encouraged members of their Inquiry Learning Forum online community to create member profiles so that they could learn more about one another. Such practice enhances social presence and provides better opportunities for online communication.

\subsection{General Standard 2}

One of the essential specific standards, namely (2.3) has linguistic significance and can be associated with Krashen's (1985) Comprehensible Input necessary for language acquisition. This standard reads as "All learning objectives are stated clearly and written from the students' perspective." According to the annotations explaining this essential specific standard, learning objectives should be "written in a way that allows students to easily grasp their meaning and the learning outcomes expected of students. The use of educational jargon, confusing terms, unnecessarily complex language, and puzzling syntax is avoided." To avoid such expected linguistic problems the fifth edition of QM Rubric focuses on writing learning objectives as competencies. 


\subsection{General Standard 3}

The "very important" specific standard 3.5 emphasizes the importance of "timely feedback to students". Students, particularly language students, learn more effectively if they receive frequent, meaningful, and timely feedback. This feedback may come from the instructor directly or even from other students. Feedback means communication and comprehension. Saville-Troike (2012) argues that feedback is a type of interaction which can enhance second language acquisition from instructors which makes learners aware that their usage is not acceptable in some way, and which provides a model for "correctness". She further adds "...corrective feedback is common in 12 and may indeed be necessary for most learners to ultimately reach native-like levels of proficiency when that is the desired goal" p.110)

\subsection{General Standard 5}

The "essential" specific standard 5.2 highlights the concept of interaction and its role in online learning. It states that "Learning activities foster instructor-student, content-student, and if appropriate to the course, student-student interaction." Meeting this quality standard will definitely support EFL learners outside the classroom. One of the main reasons behind slow development of a foreign language is the lack of opportunities for interaction and practice outside the classroom. Designing online courses with guidance from QM Rubric will compensate this gap. Such course designing has to meet the essential standards in order to be recognized by Quality Matters.

Interaction is considered as the genesis of language. According to the socio-cultural approach (Vygotsky, 1962, 1978) interaction not only facilitates language learning but is a causative force in acquisition; further, all of learning is seen as essentially a social process which is grounded in socio-cultural settings. The essential role of interaction in language acquisition shows how significant is substandard 5.2 which must be met if the course is to be recognized when submitted for review by QM experts.

EFL instructors in EFL contexts have expressed their concern about their students' reluctance to participate in English inside and outside the classroom, (Al Zubeiry, 2012; Hamouda, 2013). Online course design based on QM Rubric can contribute to solving this problem since "interaction opportunities" are a prerequisite for the recognition of such courses. The online presentation of the content can encourage reluctant and shy students to participate more comfortably. Moreover, online interaction makes them more autonomous, less isolated and connects them with fellow students and with their instructor. It makes them more inclined to share thoughts with their peers.

\subsection{General Standard 8}

This general standard contains a "very important" specific standard (8.2) which, if met, in a language online course design will enhance the EFL learning environment and make the content more authentic. This specific standard states that "The course contains equivalent alternatives to auditory and visual content." These alternatives are important for authentic language. They vary the content mode. A dialogue, for example, can be written, auditory or a video. This feature of an online course design helps in EFL learners' exposure to real and immediate input. Such variation in L2 input was difficult to get before introducing technology in language teaching and learning. Quality Matters Rubric considers it "very important" to design an online course with equivalent textual representations of images, audio, animations, and videos. Such design creates an environment conducive to better English language learning. The examples below from the Rubric annotations illustrate how the existence of such alternatives can be very useful to learners with certain disabilities.

1) An audio lecture has a text transcript available.

2) A video clip, image, or animation is accompanied by a text transcript.

3) Text provides an alternative to non-text content in web pages. It is especially helpful for people who are blind and rely on a screen reader to have the content of the website read to them.

4) Videos and live audio have captions and a transcript. With archived audio, a transcription may be sufficient.

Technology makes learning and more autonomous and possible for all. Quality Matters course designing regulates this possibility.

\section{Conclusion}

In response to the interests of the digital natives generation, design-based research has been busy attempting to meet this generations' learning requirements. Technology-based spaces have been created to contribute to meeting these interests. However, the challenge that emerged with these new environments is maintaining the humanized nature of traditional learning environments especially in foreign language teaching where social 
presence is vital for language acquisition.

Quality Matters Rubric with its general standards, specific standards and annotations has been observed to have the potential to play a vital role in learning English or any other foreign language provided that the language courses stick to the design as suggested by the Rubric. A deep look at the standards has resulted in a great potential of some specific standards to foster and enhance foreign language learning. The analysis of these standards has indicated a strong match between the QM Rubric and the theories of language learning. It has been noticed that some essential and very important standards consider communicative competence, feedback, comprehensible input, multi-dimensional interaction and various modes of content presentation prerequisites for the recognition and accreditation of an online or blended course quality. Being an institutionalized peer-review and faculty-centered process QM course design is likely to yield fruitful results in the field of foreign language in general and EFL in particular.

\section{References}

Akyol, Z., \& Garrison, D. R. (2011). Understanding cognitive presence in an online and blended community of inquiry: Assessing outcomes and processes for deep approaches to learning. British Journal of Educational Technology, 42(2), 233-250. http://dx.doi.org/10.1111/j.1467-8535.2009.01029.x

Al-Zubeiry, H. (2012). The Socio-psychological Orientations of Saudi Learners of English as a Foreign Language. Umm Al-Qura University Journal \& of languages \& literature, 8, 11-52.

Argyle, M., \& Dean, J. (1965). Eye-contact, distance and affiliation. Sociometry, 28, 289-304. http://dx.doi.org/10.2307/2786027

Barab, S. A., MaKinster, J. G., \& Scheckler, R. (2003). Designing system dualities: Characterizing a web-supported professional development community. The Information Society, 19, 237-256. http://dx.doi.org/10.1080/01972240309466

Bolliger, D., \& Inan, F. (2012). Development and Validation of the Online Student Connectedness Survey (OSCS). The International Review of Research in Open and Distance Learning, 13(3), 41-65. Retrieved from http://www.irrodl.org/index.php/irrodl/article/view/1171/2206

DuCharme-Hansen, B. A., \& Dupin-Bryant, P. A. (2005). Distance Education Plans: Course Planning for Online Adult Learners. TechTrends, 49(2), 31-39. http://dx.doi.org/10.1007/BF02773969

Garrison, D., Anderson, T., \& Archer, W. (2000). Critical inquiry in a text-based environment: Computer conferencing in higher education. The Internet and Higher Education, 2, 87-105. http://dx.doi.org/10.1016/S1096-7516(00)00016-6

Hamouda, A. (2013). An Exploration of causes of Saudi Student' reluctance to participate in the English Language Classroom. Intentional Journal of English Language Education, 1(1), 17-34. http://dx.doi.org/10.5296/ijele.v1i1.2652

Jonassen et al. (1999). Designing constructivist learning environments. In C. M. Reigeluth (Ed.), Instructional design theories and models: A new paradigm of instructional theory (Vol. II, pp. 215-239). New Jersey: Lawrence Erlbaum Associates.

Jones, P., Kolloff, M., \& Kolloff, F. (2008). Students' Perspectives on Humanizing and Establishing Teacher Presence in an Online Course. In K. McFerrin et al. (Eds.), Proceedings of Society for Information Technology and Teacher Education International Conference 2008 (pp. 460-465). Chesapeake, VA: AACE.

Kelly, A. E. (2004). Design Research in Education: Yes, but is it Methodological? Journal of the Learning Sciences, 13(1), 115-128. http://dx.doi.org/10.1207/s15327809j1s1301_6

Krashen, S. (1985). The Input Hypothesis: Issues and Implications. New York: Longman.

Legon, R., Runyon, J., \& Aman, R. (2007, October). The impact of "Quality Matters" standards on courses: Research opportunities and results. Paper presented at the13th International Sloan-C Conference on Online Learning, Orlando, FL.

MarylandOnline. (2013). Quality Matters overview. Retrieved from https://www.qualitymatters.org/applyingrubric-15/download/QM_Overview_for\%20Current\%20Subscribers_AE2013.pdf

Mehrabian, A., \& Wiener, M. (1966). Non-immediacy between communicator and object of communication in a verbal message: Application to the inference of attitudes. Journal of Consulting Psychology, 30, 420-425. http://dx.doi.org/10.1037/h0023813 
Moore, M., \& Kearsley, G. (1996). Distance Education: A Systems View. California: Wadsworth.

Picciano, A. (2002). Beyond student perceptions: Issues of interaction, presence, and performance in an online course. Journal of Asynchronous Learning Networks, 6(1), 21-40.

Richardson, J. C., \& Swan, K. (2003). Examining social presence in online courses in relation to students' perceived learning and satisfaction. Journal of Asynchronous Learning Networks, 7(1), 68-88.

Rovai, A. P., \& Barnum, K. T. (2003). On-Line course effectiveness: An analysis of student interactions and perceptions of learning. Journal of Distance Learning, 18(1), 57-73. Retrieved from http://topshare.che.nl/downloadattachment/177224/Artikel\%20over\%20eff\%20van\%20online\%20studeren. pdf

Saville-Troike, M. (2012). Introducing Second Language Acquisition. Cambridge: Cambridge University Press. http://dx.doi.org/10.1017/CBO9780511888830

Short, J., Williams, E., \& Christie, B. (1976). The social psychology of communication. New York: John Wiley.

Swan, K. P., Richardson, J. C., Ice, P., Garrison, D. R., Cleveland-Innes, M., \& Arbaugh, J. B. (2008). Validating a measurement tool of presence in online communities of inquiry. E-mentor, 2(24).

Vygotsky, L. S. (1962). Thought and Language. Cambridge MA: MIT Press. http://dx.doi.org/10.1037/11193-000

Vygotsky, L. S. (1978). Mind in society: The development of higher psychological processes. Cambridge, MA: Harvard University Press.

Wegerif, R. (1998). The social dimensions of asynchronous learning networks. Journal of Asynchronous Learning Networks, 2(1), 34-49. Retrieved from http://www.sloan-c.org/publications/jaln/v2n1/pdf/v2n1_ wegerif.pdf

\section{Copyrights}

Copyright for this article is retained by the author(s), with first publication rights granted to the journal.

This is an open-access article distributed under the terms and conditions of the Creative Commons Attribution license (http://creativecommons.org/licenses/by/3.0/). 